\author{
ACTA MYCOLOGICA \\ Vol. 48 (1): 27-32 \\ 2013
}

DOI: $10.5586 / \mathrm{am} .2013 .004$

\title{
Site characteristics of Tuber magnatum in Greece
}

\author{
VASILIOS CHRISTOPOULOS ${ }^{1}$, POLYXENI PSOMA² \\ and STEPHANOS DIAMANDIS ${ }^{1}$
}

\begin{abstract}
${ }^{1}$ HAO-Forest Research Institute, EL-570 06 Vassilika, Thessaloniki, diamandi@fri.gr ${ }^{2}$ HAO-Soil Science Institute, EL-570 01 Thermi, Thessaloniki
\end{abstract}

Christopoulos V., Psoma P., Diamandis S.: Site characteristics of Tuber magnatum in Greece. Acta Mycol. 48 (1): 27-32, 2013.

Day after day it is being demonstrated that Greece hides a buried treasure in its forests. The wild black truffles Tuber aestivum, T. uncinatum, T. brumale and T. melanosporum and the white truffle $T$. borchii and recently $T$. magnatum are picked in a variety of forest ecosystems all over the country. The information which has been collected has initiated a national programme on truffle cultivation which, so far, has immense appeal, especially among young farmers. The discovery of carpophores of T. magnatum, the most valued white truffle in the market, triggered the interest in studying the site characteristics, botanical and pedological, in order to help farmers to cultivate the species in similar sites. All carpophores were found under hornbeam (Carpinus orientalis) along the banks of a creek on alluvial sediment. Soil analyses of four soil samples from truffle nests showed a narrow range of values of $\mathrm{pH}$ in water (7.57-7.78) and 1N KCL (6.94-7.07) and a similar granulometric soil texture.

Key words: white truffle, soil analyses, ecology and distribution, truficulture

\section{INTRODUCTION}

Over the last fifteen years there has been considerable hope and speculation that since the forests and soil types in Greece are similar to those of neighbouring Italy, truffles should exist in Greece too. Due to a lack of data, however, these hopes could not be proven. The first specimen of an immature carpophore of T. aestivum Vittad. (black summer truffle) was officially sent to the Forest Research Institute in 2003. The specimen was identified by Dr Stephanos Diamandis and then confirmed by Prof. Maria Lawrynowicz from Lodz University, Poland. Soon afterward, a series of seminars was initiated by the Forest Research Institute in areas of Greece deemed suitable for truffle. This resulted in the emergence of truffle hunters who sent in a great deal of data confirming that the climatic and soil conditions as well as host trees in Greece were suitable for truffle growing. 
Black truffles of commercial interest, such as Tuber aestivum (summer truffle), T. uncinatum Chatin (Bourgundy truffle), T. brumale Vittad. (winter truffle), T. melanosporum Vittad. and the white truffles, T. borchii Vittad. (biancetto) and T. excavatum, growing in the wild are now picked in a variety of forest ecosystems all over the country (Diamandis and Perlerou 2008). A remarkable number of young farmers have responded positively to a national programme encouraging truffle cultivation. All of the species mentioned above are now cultivated in a variety of mountain areas from the northern border all the way down to Crete, with the exception of T. magnatum Pico which had never been found in Greece. Recently, however, the Forest Research Institute received its first specimens of T. magnatum (Figs 1 and 2), which is widely considered as the most valued but at the same time the most difficult truffle to find and to cultivate.

These are the first preliminary results in an attempt to study the site characteristics of T. magnatum truffle-beds in Greece in order to encourage its cultivation in similar sites. The authors, respecting the wish of the collectors, do not provide any geographical information about specific locations.

\section{MATERIALS AND METHODS}

The site features, botanical and soil physico-chemical characteristics, were studied during a field visit to the one single location where the first white truffles had been collected. Soil samples were received from four truffle-nests along a creek where carpophores had been collected. A core of soil $30 \mathrm{~cm}$ deep was removed by using a common vertical spade and transferred into plastic bags. Four such soil samples were taken $15 \mathrm{~cm}$ away from an equal number of truffle-nests and one additional soil sample was taken from the same area but away from truffle-nests to be used as control. The distance between the first and the last truffle-nest was about $300 \mathrm{~m}$.

The soil analyses were carried out by using standard laboratory methods. In particular, the soil texture was determined by the Hydrometer Method (Gee, Bauder 1986; Gee, Or 2002). Metal concentrations ( $\mathrm{Fe}, \mathrm{Zn}, \mathrm{Mn}$ and $\mathrm{Cu}$ ) were determined by using Inductively Coupled Plasma Emission Spectroscopy (ICP) after extraction with DTPA solution at pH 7.3 (Lindsay, Norvell 1978). The $\mathrm{pH}$ was assessed both in a saturation paste and in a solution of 1:1 of $1 \mathrm{~N} \mathrm{KCL}$. The chemical parameters that were also determined were total $\mathrm{CaCO} 3$ by back titration (Piper 1942), organic matter by the wet digestion method (Walkley, Black's 1934), Phosphorus (P) by the Olsen method (Olsen et al. 1954), Potassium (K), Calcium (Ca) and Magnesium (Mg) by the ammonium acetate method (Knudsen et al. 1982) and Boron (B) by the hot water method (Bingham 1982).

The results of the analyses are demonstrated in Table 1.

\section{RESULTS}

The area referred to is only $15 \mathrm{~km}$ away from the sea. The climate is Mediterranean with warm, wet winters and a long dry season through summer. Annual mean temperature in 2012 was $16^{\circ} \mathrm{C}$ while mean minimum was $10.8^{\circ} \mathrm{C}$. Total precipitation in 2012 was $775.2 \mathrm{~mm}$. 


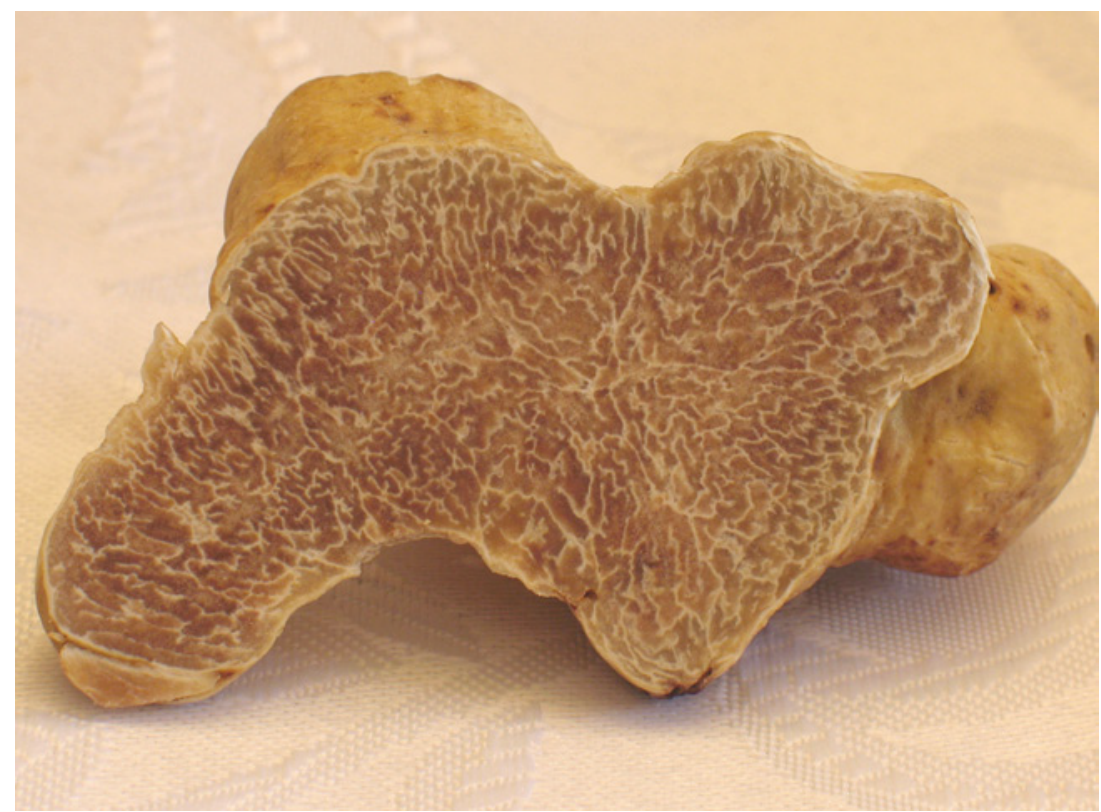

Fig. 1. Carpophore of Tuber magnatum showing irregular, lobed and compressed shape as well as decoration of gleba.

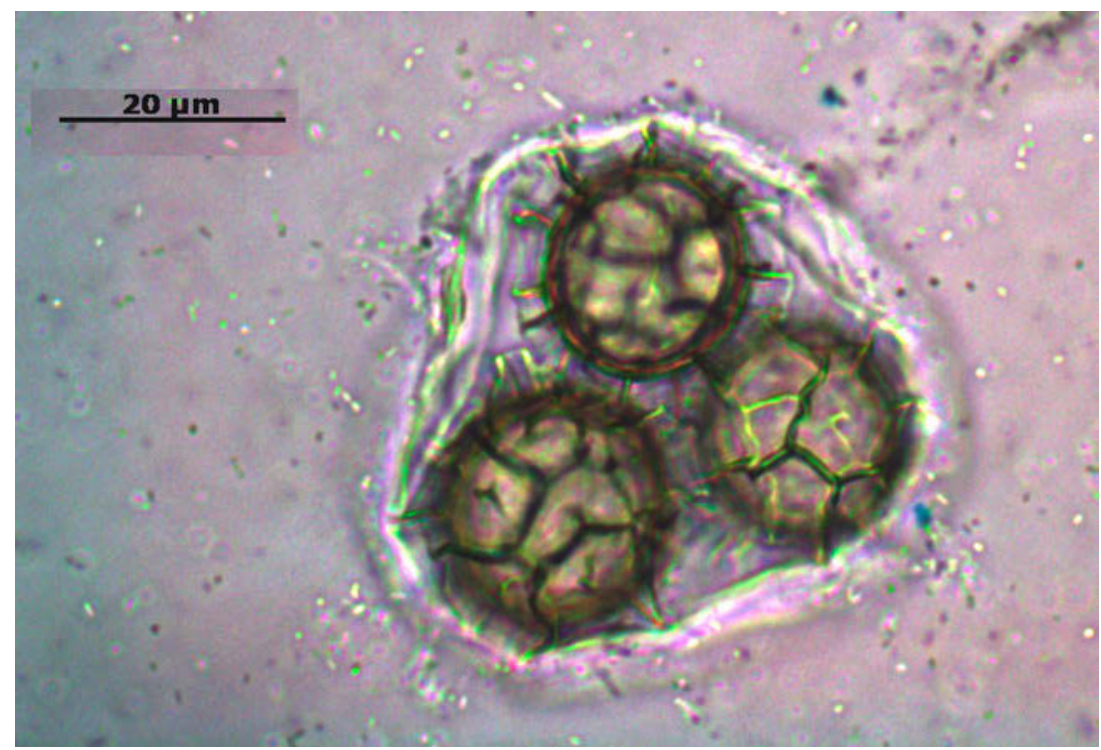

Fig. 2. Tuber magnatum. Ascus with three broadly ellipsoid ascospores.

The carpophores of T. magnatum were collected at the banks of a narrow creek with steep sides and under natural Carpinus orientalis. Other tree species along the creek were Quercus pedunculiformis, Salix sp. and Corylus avellana while the dominant plant of the undergrowth was Ruscus aculeatus. 
The specific truffle-nests were located $50-80 \mathrm{~cm}$ above the water surface on rich soil that had accumulated on the narrow banks by falling from the steep sides. There was an abundance of thin tree roots around the nests. According to the figures reached by granulometry, the soil structure is defined as L to CL.

The results of the soil analyses showed that soil around the truffle-nests is alkaline with the $\mathrm{pH}$ values ranging between 7.57 and 7.78. $\mathrm{pH}$ values in KCL also had a narrow range, 6.94 to 7.07 . The $\mathrm{pH}$ values of the control sample were not significantly different. The values of all parameters, except those of $\mathrm{K}$ and $\mathrm{Ca}$ content, between the four truffle soil samples and the control soil sample were not significantly different either. $\mathrm{K}$ and $\mathrm{Ca}$ content in the control sample were, however, significantly higher. Results of the soil analyses are shown in Table 1.

Table 1

Results of soil analyses. Samples B1-B4 refer to truffle-nest samples.

B5 refers to the control sample

\begin{tabular}{|c|c|c|c|c|c|c|c|c|c|c|}
\hline Sample no. & $\begin{array}{c}\text { Soil } \\
\text { struc } \\
\text { ture }\end{array}$ & $\begin{array}{c}\text { Clay } \\
\%\end{array}$ & $\begin{array}{l}\text { Silt } \\
\%\end{array}$ & $\underset{\%}{\text { Sand }}$ & $\begin{array}{l}\mathrm{pH} \text { in } \\
\mathrm{H}_{2} \mathrm{O}\end{array}$ & $\begin{array}{l}\mathrm{pH} \text { in } \\
\mathrm{KCL}\end{array}$ & $\begin{array}{c}\mathrm{Ec} \\
\mathrm{mS} / \\
\mathrm{cm}\end{array}$ & \multicolumn{2}{|c|}{$\begin{array}{c}\mathrm{CaCO}_{3} \\
\%\end{array}$} & $\begin{array}{c}\text { Organic } \\
\text { matter } \%\end{array}$ \\
\hline B1 & $\mathrm{CL}$ & 34 & 32.0 & 34.0 & 7.78 & 7.07 & 0.89 & \multicolumn{2}{|c|}{70} & 5.81 \\
\hline B2 & $\mathrm{CL}$ & 30 & 34.0 & 36.0 & 7.65 & 6.94 & 0.79 & \multicolumn{2}{|c|}{0.3} & 5.24 \\
\hline B3 & $\mathrm{L}$ & 18 & 44.0 & 38.0 & 7.57 & 7.02 & 0.48 & \multicolumn{2}{|c|}{1.5} & 2.01 \\
\hline B4 & $\mathrm{CL}$ & 34 & 32.0 & 34.0 & 7.60 & 7.02 & 0.84 & \multicolumn{2}{|c|}{5.0} & 6.61 \\
\hline B5 control & $\mathrm{CL}$ & 28 & 34.0 & 38.0 & 7.84 & 7.25 & 0.86 & \multicolumn{2}{|c|}{20.0} & 5.46 \\
\hline Sample no. & $\begin{array}{l}\text { NO3 } \\
\text { ppm }\end{array}$ & $\begin{array}{c}\mathrm{P} \\
\mathrm{ppm}\end{array}$ & $\begin{array}{c}\mathrm{K} \\
\mathrm{ppm}\end{array}$ & $\begin{array}{l}\mathrm{Mg} \\
\mathrm{ppm}\end{array}$ & $\begin{array}{c}\mathrm{Fe} \\
\mathrm{ppm}\end{array}$ & $\begin{array}{c}\mathrm{Zn} \\
\mathrm{ppm}\end{array}$ & $\begin{array}{l}\mathrm{Mn} \\
\mathrm{ppm}\end{array}$ & $\begin{array}{c}\mathrm{Cu} \\
\mathrm{ppm}\end{array}$ & $\begin{array}{c}\text { B } \\
\text { ppm }\end{array}$ & $\begin{array}{c}\mathrm{Ca} \\
\mathrm{ppm}\end{array}$ \\
\hline B1 & 23.99 & 6.92 & 159 & 195 & 26.13 & 1.11 & 19.22 & 1.31 & 0.73 & 5960 \\
\hline B2 & 31.01 & 2.19 & 142 & 181 & 24.49 & 1.36 & 13.30 & 1.05 & 0.85 & 3679 \\
\hline B3 & 10.92 & 1.79 & 69 & 106 & 17.54 & 0.46 & 7.03 & 0.62 & 0.53 & 3661 \\
\hline B4 & 46.80 & 3.24 & 143 & 194 & 29.66 & 1.70 & 19.64 & 1.81 & 0.73 & 5730 \\
\hline B5 control & 45.83 & 4.45 & 268 & 193 & 28.49 & 1.40 & 21.66 & 1.48 & 0.98 & 7879 \\
\hline
\end{tabular}

Table 2 shows the range of values of the physico-chemical variables between the truffle-nests and the control sample which were determined.

Table 2

Comparative range of physico-chemical soil variables between truffle-nest soil and control

\begin{tabular}{|c|c|c|c|c|c|c|c|c|c|c|c|}
\hline Sample & $\underset{\%}{\text { Clay }}$ & Silt \% & \multicolumn{2}{|c|}{ Sand \% } & $\begin{array}{l}\mathrm{pH} \text { in } \\
\mathrm{H}_{2} \mathrm{O}\end{array}$ & \multicolumn{2}{|c|}{$\mathrm{pH}$ in $\mathrm{KCL}$} & \multicolumn{2}{|c|}{$\mathrm{Ec} \mathrm{mS} / \mathrm{cm}$} & $\begin{array}{c}\mathrm{CaCO}_{3} \\
\%\end{array}$ & $\begin{array}{c}\text { Organic } \\
\text { matter \% }\end{array}$ \\
\hline $\begin{array}{c}\text { Truffle- } \\
\text { nests }\end{array}$ & $18-34$ & $32-44$ & \multicolumn{2}{|c|}{$34-38$} & $\begin{array}{l}7.57- \\
7.78\end{array}$ & \multicolumn{2}{|c|}{$6.94-7.07$} & \multicolumn{2}{|c|}{$0.48-0.89$} & $0.3-7.0$ & $2.01-5.81$ \\
\hline Control & 28 & 34 & \multicolumn{2}{|l|}{38} & 7.84 & & 7.25 & \multicolumn{2}{|c|}{0.86} & 20.0 & 5.46 \\
\hline Sample & $\begin{array}{l}\text { NO3 } \\
\text { ppm }\end{array}$ & $\begin{array}{c}\mathrm{P} \\
\mathrm{ppm}\end{array}$ & $\begin{array}{c}\mathrm{K} \\
\mathrm{ppm}\end{array}$ & $\begin{array}{r}\mathrm{Mg} \\
\mathrm{ppm}\end{array}$ & & & $\begin{array}{c}\mathrm{Zn} \\
\mathrm{ppm}\end{array}$ & $\begin{array}{r}\mathrm{Mn} \\
\mathrm{ppm}\end{array}$ & $\begin{array}{c}\mathrm{Cu} \\
\mathrm{ppm}\end{array}$ & B ppm & Ca ppm \\
\hline $\begin{array}{c}\text { Truffle- } \\
\text { nests }\end{array}$ & $\begin{array}{l}10.92- \\
46.80 \\
\end{array}$ & $\begin{array}{l}1.79- \\
6.92 \\
\end{array}$ & $\begin{array}{l}69- \\
159 \\
\end{array}$ & $\begin{array}{l}106- \\
195 \\
\end{array}$ & & $\begin{array}{l}54- \\
66\end{array}$ & $\begin{array}{l}0.46- \\
1.71 \\
\end{array}$ & $\begin{array}{l}7.03- \\
19.64 \\
\end{array}$ & $\begin{array}{c}0.62- \\
1.81\end{array}$ & $\begin{array}{l}0.53- \\
0.85 \\
\end{array}$ & $3661-5960$ \\
\hline Control & 45.83 & 4.45 & 268 & 193 & & 49 & 1.40 & 21.66 & 1.48 & 0.80 & 7879 \\
\hline
\end{tabular}


The $\mathrm{CaCO}_{3}$ content of the control sample appears significantly higher (20.0) than the soil around the truffle-nests (0.3-7.0). Significantly higher is also the $\mathrm{K}$ and $\mathrm{Ca}$ content. All five samples which came from the same soil horizon had good porosity and drainage, satisfactory aeration and weakly developed granular structure whereas the clay content ensured persistent minimum moisture.

\section{DISCUSSION}

Carpophores of Tuber magnatum are recorded in the wild for the first time in Greece. As interest in truffle cultivation is steadily growing, an effort was undertaken to analyze the soil around the first white truffle-nests in order to be able to promote white truffle cultivation in cases where soils are similar in physical and chemical properties.

The present work is a first approach based on a limited number of soil samples taken from truffle-nests along a creek at a single location. Therefore, they can be considered only as preliminary results. The particular fungus at the specific location seems to create mycorrhiza with Carpinus orientalis. Its occurrence on alluvial calcareous deposits comes in agreement with habitats in Italy where the fungus is intensely hunted (Lulli, Primavera 2001; Raglione, Owczarek 2005). As with T. melanosporum, the physico-chemical characteristics of the soils may show a strong variability within each parameter (Bencivenga et al. 1988; Poitou 1988; Raglione et al. 1992, 2001). In our case the soil analyses showed a narrow variability, especially in the values of $\mathrm{pH}$ in water and $1 \mathrm{~N} \mathrm{KCL}$, as well as in the other chemical parameters determined among the truffle-nests, but this is to be expected since the soil samples came from the same alluvial deposits along the same creek. Corresponding values of the control soil sample did not differ significantly from those of the truffle-nests except those of $\mathrm{CaCO} 3, \mathrm{~K}$ and $\mathrm{Ca}$ content. The limited number of samples, however, does not allow any conclusions to be drawn regarding their significance.

Acknowledgments. The authors would like to thank Ms. E. Tziatziou and Mr. V. Goulandas who found the truffles and helped to collect the soil samples. Anonymous reviewers are thanked for valuable suggestions to improve this manuscript.

\section{REFERENCES}

Bencivenga M., Calandra R., Granetti B. 1988. Ricerche sui terreni e sulla flora delle tartufaie naturali di Tuber melanosporum Vitt. Dell'Italia Cebtrale. Atti "Il Congresso Internationale sul Tartufo", Spoleto, 24-27 November 1988: 337-374, Italy.

Bingham F.T. 1982. Boron. (In:) A.L. Page (ed.). Methods of soil analysis. 2. Agronomy Mongraph. 2nd edition, Madison.

Diamandis S. Perlerou C. 2008. Recent records of hypogeous fungi in Greece. Acta Mycol. 43 (2): 139 142.

Gee G.W., Bauder J.W. 1986. Particle-size analysis. (In:) A. Klute (ed.) Methods of soil analysis. Soil Science Society of America; Book Series 5, Madison: 383-411.

Gee W.G., Or D. 2002. Particle-size analysis. (In:) H.D Jacob, T.G Clarke, A.D Warren (eds). Methods of soil analysis. Soil Science Society of America, Madison: 151-184. 
Knudsen D., Peterson, G.A., Pratt P.F. 1982. Lithium, sodium and potassium (In:) A.L. Page (ed.). Methods of soil analysis. 1. Agronomy Monograph. 2nd edition, Madison.

Lulli L., Primavera F. 2001. Tuber magnatum Pico: Environment of growth. (In:) Actes du Ve Congres International "Science et culture de la truffe", Aix en Provence, 4-6 Mars 1999: 269-272, France.

Lindsay W.L., Norvell W.A. 1978. Development of a DTPA Soil Test for Zinc, Iron, Manganese and Copper. Soil Science Society of America Journal 42: 421-428.

Olsen S.R., Cole C.V., Watanabe F.S., Dean L.A. 1954. Estimation of available phosphorus in soils by extraction with sodium bicarbonate. US Dept. of Agric. Circ. 939.

Piper C.S. 1942. Soil and Plant analysis. Hassel press, Adelaide, Australia.

Poitou N. 1988. Les sols truffiers francais. Atti "Il Congresso Internationale sul Tartufo", Spoleto, 24-27 November 1988: 391-401, Italy.

Raglione M., Lorenzoni P., De Simone C., Monaco R., Angius A. 1992. Osservazioni sulle caratteristiche pedologiche di alcuni siti di Tartufo nero pregiato (Tuber melanosporum) in provincia di Rieti. Micologia e Vegetazione Mediterranea 7 (1): 211-224.

Raglione M., Spadoni M., Cavelli S., Lorenzoni P., De Simone C. 2001. Les sols des truffieres naturelles de Tuber melanosporum Vitt. Dans l'Apennin central (Italie). Actes du Ve Congres International "Science et culture de la truffe", Aix en Provence, 4-6 Mars 1999: 276-280, France.

Raglione M., Owczarek M. 2005. The soils of natural environments for growth of truffles in Italy. Mycologia Balcanica 3 (2): 209-216.

Walkley A., Black I.A. 1934. An Examination of the Degtjareff Method for Determining Soil Organic Matter, and a Proposed Modification of the Chromic Acid Titration Method. Soil Science 37: 29-38. http://dx.doi.org/10.1097\%2F00010694-193401000-00003 